\title{
Listy Jana Lemańskiego do Stefana Żeromskiego i jego rodziny
}

\section{BEATA UTKOWSKA}

(Uniwersytet Jana Kochanowskiego w Kielcach)

Jan Lemański (I866-I933) - młodopolski poeta, satyryk, bajkopisarz i tłumacz wszedł do warszawskiego środowiska literackiego około roku i894. Swoje pierwsze utwory: przekład baśni Hansa Christiana Andersena pt. Historia pewnej mitości oraz debiutancką nowelę Czarna topiel opublikował w konserwatywnej „Niwie” ( 1894, nr 4 i 7), ale wkrótce związał się z redakcją postępowego i demokratycznego „Głosu” (I886-I899) Jana Ludwika Popławskiego i Józefa Karola Potockiego, w którym od wiosny I896 r. drukował wierszowane bajki, satyry i poezje. Do grona jego znajomych należeli wówczas redaktorzy i współpracownicy pisma, m.in. Zygmunt Wasilewski, Władysław Jabłonowski, Antoni Lange, Władysław Stanisław Reymont ${ }^{\mathrm{I}}$.

Z pewnością też na łamach „Głosu” Lemański zetknął się z twórczością Stefana Żeromskiego, który w latach I889-I894 zamieścił tu kilka korespondencji z Nałęczowa, Stopnicy i Krakowa oraz niemal wszystkie swoje młodzieńcze opowiadania (m.in. Po Sedanie, Pokusa, Sitaczka, Zapomnienie, Zmierzch, Doktor Piotr). Osobiście mogli się jednak poznać dopiero po powrocie Żeromskiego z Rapperswilu $\mathrm{w}$ drugiej połowie $1896 \mathrm{r}$. lub (co jest bardziej prawdopodobne) na początku roku ı897, kiedy Żeromscy przeprowadzili się na stałe do Warszawy². Wydaje się, że od

1 J. Kwiatkowski, Jan Lemański, w: Polski stownik biograficzny (dalej skrót: PSB), red. E. Rostworowski, t. 17, Wrocław-Warszawa-Kraków 1972, s. 29-30. Wydaje się, że w tamtym okresie najbliższe stosunki łączyły Lemańskiego z Reymontem: jesienią 1895 r. (wspólnie z Langem) wynajmowali mieszkanie w Warszawie przy Nowym Świecie 52, Lemański bywał też w rodzinnej Wolbórce Reymonta i w domu jego siostry, Katarzyny Jakimowiczowej (zob. W.S. Reymont, Dziennik nieciagty. 1887-1924, oprac. B. Utkowska, Kraków 2009, s. 197).

2 Zob. S. Żeromski, Pisma zebrane, red. Z. Goliński, t. 36: Listy 1897-1904, oprac. Z.J. Adamczyk, Warszawa 2003, s. 11. 
początku były to relacje serdeczne ${ }^{3}$. Kontakty zawodowe utrzymywali w latach współpracy Lemańskiego z „Chimerą” (I90I-I907), ale najintensywniejsze, również towarzyskie stosunki, nawiązali w latach następnych: 1907-I9I2. Poeta parokrotnie bywał wówczas u Żeromskich w Nałęczowie, dużą sympatią (chyba odwzajemnioną) darzył żonę pisarza, Oktawię i ich kilkuletniego syna, Adasia.

Świadectwem tych kontaktów jest zachowana korespondencja Lemańskiego ze Stefanem Żeromskim i jego rodziną z lat I904-I9I2. Listy Lemańskiego mają różny charakter. Bywają skoncentrowane na sprawach wówczas głośnych, interesujących opinię publiczną (protest w obronie „Chimery” i Miriama, kwestia sprowadzenia zwłok Juliusza Słowackiego do kraju), niektóre podejmują tematy literackie czy zawodowe ważne przede wszystkim dla samych korespondentów (wydanie Dumy o hetmanie, pomysł objęcia przez Lemańskiego stanowiska sekretarza Towarzystwa Pisarzy Polskich), są wreszcie kartki niezobowiązujące, stanowiące jedynie wyraz życzliwej pamięci (wierszowane pozdrowienia, życzenia noworoczne). Ze wszystkich jednak przebija ogromny szacunek autora Popiotór $w^{4}$ - nie ma w tych listach poufałości, mimo że styl Lemańskiego z reguły jest lekki i żartobliwy. Na dużo więcej swobody pozwala sobie nadawca w kartkach pisanych do Oktawii (oraz, co zrozumiałe, do Adasia) - to one odtwarzają ciepły klimat nałęczowskich spotkań, wskazują na przyjacielskie stosunki panujące między Lemańskim a rodziną Żeromskiego.

Publikowane tu listy (w tym również kartki pocztowe, telegram, bilety wizytowe) Lemańskiego do Stefana, Oktawii i Adasia Żeromskich pochodzą ze zbiorów Biblioteki Narodowej (dalej skrót: BN) - kartka do Oktawii z 8 kwietnia I9I2 r. znajduje się w zespole Korespondencji i papierów Oktawii z Radziwittorwiczów Żeromskiej, Iv. Rodkiewiczowej (rkps 7349, k. 9), pozostałe przechowywane są w ogromnym bloku Korespondencji Stefana Żeromskiego pod sygnaturą akc. I7 218, t. 2I. Trzy $\mathrm{z}$ tych listów ( 7 lipca I904 r., 8 stycznia I9Io r. oraz 8 kwietnia I9I2 r.) były we fragmentach lub w całości przedrukowywane (adresy bibliograficzne przedruków podane zostały w metryczkach listów), pozostałe ogłaszane są po raz pierwszy.

3 W dniu 15 września 1897 r. Reymont, chyba nieco zazdrosny o zainteresowanie Lemańskiego, pisał do Jana Lorentowicza: „Tego [Lemańskiego - B. U.] bardzo kocham zawsze, a on zaś rozdziela serce pomiędzy mną a Żeromskim" (W.S. Reymont, Korespondencja 1890-1925, oprac. B. Koc, Warszawa 2002, s. 217).

4 Szacunek chyba nieudawany - nie podważa go satyryczny wiersz Lemańskiego o Popiołach, we fragmentach przedrukowany przez Wacława Borowego w tomie O Żeromskim. Rozprawy i szkice (Warszawa 1964, s. 295-297). 
W opracowaniu tekstologicznym i edytorskim przyjęto następujące zasady: - w prawym górnym rogu podano (często rekonstruowaną) datę listów. Lemański w korespondencji konsekwentnie używał dat według nowego stylu, choć z reguły - jeśli porówna się te daty ze stemplami pocztowymi - robił to nieprecyzyjnie, wyprzedzając lub cofając czas o jeden, dwa, a nawet o trzy dni, np. podawał datę 30 stycznia, a na warszawskim datowniku pocztowym widnieje data I9 stycznia (wg starego stylu). Postanowiono utrzymać autorskie datowanie według kalendarza gregoriańskiego. Oznacza to, że te listy, w których Lemański pominął datę i które zostały uporządkowane na podstawie rosyjskich stempli pocztowych, otrzymały w górnym prawym rogu datę według nowego stylu (data stempla plus I3 dni, odpowiadających różnicy między kalendarzem juliańskim a gregoriańskim w XIX wieku);

- zachowano oboczne końcówki biernika 1. poj. rodzaju żeńskiego (,jednę”/,jedną") oraz formy dawne, notowane przez ówczesne słowniki (np. „stronnica”, „poszlę”);

- zmodernizowano pisownię końcówek narzędnika 1. poj.i 1. mn. przymiotników i zaimków z ,-em”, ,-emi” na „-ym”, ,-ymi” (np. „w tym kochanym” zamiast „w tem kochanem"), z wyjątkiem pozycji rymowych w wierszach;

- uwspółcześniono interpunkcję i ortografię, poprawiono też (zgodnie z dzisiejszymi zasadami) pisownię obcojęzycznych nazw własnych (np. „Shelley” zamiast „Schelley”, „Abbazia” zamiast „Abazia”);

- skróty autorskie („Kur. Warsz.”) i konwencjonalne (ks.), również obcojęzyczne, pozostawiono, ale te konwencjonalne zapisano zgodnie $\mathrm{z}$ dzisiejszymi normami słownikowymi (No jako nr, Śty jako św.), zachowano też zgodną z rękopisem pisownię liczebników (np. cyfra połączona z kocówką fleksyjną);

- nawiasy kwadratowe pochodzące od autora zastąpiono okrągłymi (kwadratowe przeznaczono dla dopisków edytorskich), natomiast autorskie wyróżnienia (w autografie podkreślenia) oddane zostały przez rozspacjowanie tekstu;

- w opisach autografów lisów, które nie mają numeracji stron ani kartek, wprowadzono umowną foliację i skróty $\mathrm{r}$ (karta recto) oraz v (karta verso).

\section{Bibliografia:}

Borowy W., O Żeromskim. Rozprawy i szkice, Warszawa 1964;

Butrym S., Budowa i dzieje ochronki im. Adama Żeromskiego w Natęczowie, w: Muzeum Stefana Żeromskiego w Natęczowie, przedmowa I. Iskrzycka, słowo wstępne F. Araszkiewicz, Nałęczów [b.r.];

Hendzel W., Ironista i marzyciel. O życiu i twórczości Jana Lemañskiego, Opole 1984;

Jabłoński J.W., Wpisany w wiek zmian: pamiętnik samorzqdowca, Pniewo 2013;

Korespondencja Stanistawa Mastowskiego, BN, rkps 7266;

Korespondencja Stefana Żeromskiego, BN, rkps akc. 17 218, t. 11, 21, 22, 40;

Korespondencja i papiery Oktawii z Radziwittowiczów Żeromskiej, 1v. Rodkiewiczowej, BN, rkps 7349; 
Kwiatkowski J., Jan Lemański, w: Polski stownik biograficzny, red. E. Rostworowski, t. 17, Wrocław-Warszawa-Kraków 1972, s. 29-31;

Legutko G., Niespokojny ptomień. Życie i twórczość Gustawa Danitowskiego, Kielce 2011;

Lemański J.W., Listy Stefana Żeromskiego do Jana Lemańskiego o Towarzystwie Literatów Polskich, „Kurier Literacko-Naukowy"1935, nr 48;

Leśmian B., Utwory rozproszone. Listy, oprac. J. Trznadel, Warszawa 1962;

Nagórska W., Prace konspiracyjno-oświatowe w Natęczowie w latach 1905-1907, w: Wspomnienia o Stefanie Żeromskim, zebrał i oprac. S. Eile, Warszawa 1961;

Pigoń S., Hajże na Miriama!, „Stolica” 1967, nr 18 (przedruk: idem, Wiazanka historycznoliteracka, Warszawa 1964, s. 316-324);

Reymont W.S., Dziennik nieciagty. 1887-1924, oprac. B. Utkowska, Kraków 2009;

Korespondencja 1890-1925, oprac. B. Koc, Warszawa 2002;

Sprawa sprowadzenia do kraju prochów Juliusza Stowackiego w roku 1909: 1. J. Zborowski, S. Żeromski i Akademicki Komitet dla Sprowadzenia Zwtok Stowackiego do Kraju, 2. S. Pigoń, Zabiegi o wzniesienie Stowackiemu grobowca w Tatrach, w: Miscellanea z pogranicza XIX i XX wieku, red. S. Pigoń, „Archiwum Literackie" t. 8, Wrocław-Warszawa-Kraków 1964, s. 425-466;

Tynecki J., Miciński - Reymont - „Chimera”, „Prace Polonistyczne” 1968, seria 24, s. 241-258;

Wawrzeniecki M., Poszukiwania zabytków przedhistorycznych w Królestwie Polskim, „Materiały Antropologiczno-Archeologiczne i Etnograficzne" 1912, t. 12, s. 34-52;

Wspomnienia o Stefanie Żeromskim, zebrał E.L. Migasiński, Warszawa 1927;

Żarnecka Z., Działalność oświatowa Faustyny Morzyckiej na tle epoki 1864-1910, Warszawa 1948;

Żeromski S., Pisma zebrane, red.Z. Goliński, kontynuacja red. Z.J. Adamczyk, t. 25: Publicystyka 1889-1919, oprac. Z.J. Adamczyk, Warszawa-Kielce 2016;

Pisma zebrane, red. Z. Goliński, t. 3: „Duma o hetmanie” i inne utwory epickie, oprac. Z. Goliński, Warszawa 1987;

Pisma zebrane, red. Z. Goliński, t. 36: Listy 1897-1904, oprac. Z.J. Adamczyk, Warszawa 2003;

Pisma zebrane, red. Z. Goliński, t. 37: Listy 1905-1912, oprac. Z.J. Adamczyk, Warszawa 2006.

SŁOWA KLUCZE: Lemański, Żeromski, korespondencja

\section{BEATA UTKOWSKA}

\section{LeTters of JAN LEMAŃSKI TO STEFAN ŻEROMSKI AND HIS FAMILY}

The article is editorial in character - it is a study proceeded with an introduction of 26 letters (mostly postcards) written by Jan Lemański to Stefan, Oktawia and Adaś Żeromski in I904-I912. Two of these letters concerning Brzozowski’s attack on Miriam and "Chimera" (Io94) and the transport of Słowacki's body to the country (I9IO) were published before. The rest, depicting the daily life, private 
relations between Lemański and Żeromski family, and also Oktawia's role as an intermediary in relations with her husband were not yet published. The whole collection is an interesting example of writers' correspondence belonging to the Young Poland movement, who wrote not only about public matters of significant importance to the whole Polish culture of the time, but also touched upon personal and family matters.

KEY words: Lemański, Żeromski, correspondence

Szanowny Kolego!

W nr. 27 „Głosu”, po całym szeregu poprzednich wycieczek przeciwko „Chimerze”, pojawił się wreszcie artykuł będący szczytem złośliwej szykany względem Miriama ${ }^{5}$. Oburzeni tym i dotknięci do żywego postanowiliśmy zaproponować Wam oraz Kasprowiczowi, Berentowi, Wyrzykowskiemu i Micińskiemu zbiorowy protest ${ }^{6}$

5 Tygodnik „Głos”, od 1900 r. redagowany przez Jana Władysława Dawida, mimo zachowania tytułu i ciągłej numeracji nie kontynuował dawnego profilu pisma. $Z$ redakcji odeszła większość starych "głosowiczów” (z Zygmuntem Wasilewskim na czele), a tygodnik stał się organem radykalnych lewicowców i socjalistów. W 1901 r. „Głos”- w serii artykułów m.in. Wacława Nałkowskiego, Ludwika Krzywickiego, Andrzeja Niemojewskiego - zaatakował Zenona Przesmyckiego, pseud. Miriam (1861-1944; biogram w PSB, t. 29) oraz wydawany przez niego miesięcznik „Chimera” (1901-1907) za elitarystyczną koncepcję sztuki i „arystokratyczny” estetyzm (kampanię przeciwko Miriamowi wywołał jego artykuł Walka ze sztuka, w którym pisał m.in. o niewykształconym „proletariacie umysłowym”, niezdolnym ocenić wysokoartystycznej sztuki; „Chimera” 1901, t. 1, z. 2). W nrze 27 „Głosu” z 1904 r. ukazał się felieton A. Czepiela (Stanisława Brzozowskiego) pt. Scherz, Ironie und tiefere Bedeutung, ostro krytykujący sztukę oderwaną od życia i przedstawiający Miriama w groteskowej scenie przemiany w porcelanową figurkę, która siedzi w kucki na komodzie i boi się rozbić.

6 Z zachowanego archiwum „Chimery” (BN, rkps 2873) wynika, że inicjatorem protestu był Lemański - bliski współpracownik i przyjaciel Miriama, sekretarz „Chimery”. To on zredagował tekst protestu, zabiegał o poparcie tych uznanych już wówczas pisarzy nowego pokolenia, którzy publikowali w „Chimerze” $\mathrm{i}$ utrzymywali z Miriamem bliskie stosunki, prowadził w tej sprawie obfitą korespondencję. Jego ręką napisane były jednakowo brzmiące listy (zmieniają się w nich jedynie nazwiska uczestników protestu) do Wacława Berenta (1873-1940), Jana Kasprowicza (1860-1926; biogram w PSB, t. 12), Tadeusza Micińskiego (1873-1918; biogram w PSB, t. 20), Stanisława Wyrzykowskiego (1869-1949), Stefana Żeromskiego (1864-1925). W proteście ostatecznie nie wziął udziału tylko Miciński. Zob. m.in. S. Pigoń, Hajże na Miriama!, „Stolica” 1967, nr 18 (przedruk: idem, Wiqzanka bistorycznoliteracka, Warszawa 1964, s. 316-324); J. Tynecki, Miciński-Reymont - „Chimera”, „Prace 
przeciw tego rodzaju chęciom zlekceważenia pracy Miriama i w ogóle człowieka tej co on miary. Przesyłamy Wam w załączeniu nr pisma, abyście rzecz sami ocenić mogli, oraz dołączamy formularz protestu, który zechcecie po podpisaniu przesłać jak najrychlej w liście rekomendowanym pod adresem jak poniżej7. Ufamy, że nie odmówicie swego współudziału w tym proteście, którym chcielibyśmy dać początek jakiejś uczciwej opinii literackiej i położyć w ten sposób tamę rozwielmożniającemu się coraz bardziej bandytyzmowi literackiemu.

Jan Lemański

Wł. St. Reymont Artur Górski ${ }^{8}$

\section{Adres: Wł. St. Reymont. Hlewin przez Nowo-Borysów. Mińska gub. \\ PS Protest wydrukujemy w „Kur. Warsz.” lub w „Tyg. Ilustr.”.}

Dwukartkowy arkusik liniowanego kremowego papieru, formatu $26 \times 2 I \mathrm{~cm}$. Tekst na k. Ir, IV, 2r, czarnym atramentem, napisany rękq Lemańskiego, podpisany wtasnoręcznie również przez Reymonta i Górskiego. Koperty brak.

Druk: S. Pigon, Hajże na Miriama!, op. cit. (przedruk: idem, Wiązanka historycznoliteracka, s. 3I9); S. Żeromski, Pisma zebrane, red. Z. Golinski, t.36: Listy 1897-1904, s. 286.

Polonistyczne" 1968, seria 24, s. 241-258; W. Hendzel, Ironista i marzyciel. O życiu i twórczości Jana Lemańskiego, Opole 1984, s. 24-26.

7 Żeromski odpowiedział listem z 12 lipca 1904 r. Wyraził w nim pełne poparcie dla Przesmyckiego i uznanie dla jego działalności artystycznej, namawiał też sygnatariuszy protestu, aby nie publikowali tekstu tegoż protestu na łamach wdającego się w ostre polemiki literackie „Kuriera Warszawskiego”. Do listu dołączył podpisany formularz protestu (zob. S. Żeromski, Pisma zebrane, red. Z. Goliński, t. 36: Listy 1897-1904, s. 284-289). List Żeromskiego (podobnie jak innych uczestników kampanii) adresowany był do Reymonta (1867-1925; biogram w PSB, t. 31), który był bliskim przyjacielem Miriama i który - jak się wydaje - jako pierwszy wsparł akcję Lemańskiego. To Reymont zbierał podpisane formularze protestu, a ponieważ w połowie lipca wyjeżdżał z żoną do Hlewina nad Berezyną w guberni mińskiej, pod takim adresem kierowane były listy.

8 Artur Górski (1870-1959) - publicysta i tłumacz związany z krakowskim „Życiem”, uznany krytyk literacki młodego pokolenia, autor cyklu programowych artykułów Mtoda Polska. Z Lemańskim oraz z rodziną Żeromskiego pozostawał w przyjaznych relacjach od końca lat dziewięćdziesiątych (zob. listy Górskiego do Adasia i Stefana Żeromskich, BN, rkps akc. 17 218, t. 11).

9 Protest ukazał się w „Tygodniku Ilustrowanym” 1904, nr 33 (z 13 sierpnia), w rubryce $Z$ tygodnia na tydzień (s. 630) i brzmiał: „W jednym z ostatnich numerów «Głosu» zjawił się artykuł pana Czepiela, napastujący Miriama i «Chimerę» w sposób pozbawiony cech polemiki ideowej i oparty jedynie na płaskich konceptach. Przeciwko podobnym traktowaniom Miriama i jego pisma protestujemy najkategoryczniej. Wacław Berent, Artur Górski, Jan Kasprowicz, Jan Lemański, Wł. St. Reymont, Stanisław Wyrzykowski, Stefan Żeromski”. 
Kochany Panie Stefanie!

[Warszawa, 28 czerwca 1907]

Najmocniej, najserdeczniej Wam dziękuję za list i zaproszenie ${ }^{\mathrm{IO}}$. Ale teraz, niestety, skorzystać z niego jeszcze nie mogę. Chyba znacznie później. Obecnie wyjeżdżam na wieś (przez Łomżę, Pniewo, u W-go Jabłońskiego ${ }^{\mathrm{II}}$ ). Przebawię tam pewno dłużej niż miesiąc. Bądźcie łaskawi napisać kilka słów, jak długo Wy tam w Nałęczowie będziecie? Poczytuję to za rzecz niezbędną, przyjechawszy tam, znaleźć Was - unum solamen ${ }^{\mathrm{I2}}$.

Proszę Was, pod powyższym adresem coś niecoś napisać.

Serdecznie Was ściskam

J. Lemański

$28 \mathrm{VI} \circ 7$

Dwukartkowy arkusik czerpanego papieru listowego koloru kremowego, formatu $24,6 \times I 7 \mathrm{~cm}$. Tekst czarnym atramentem na k. Ir i 2 r. Koperty brak.

3.

Kochany Panie Stefanie!

[Warszawa, początek I908] ${ }^{13}$

Zwracam Dzieje [grzechu] i przypominam o obiecanym egzemplarzu moim.

Jutro z powodów rodzinnych nie będę u Państwa o I-ej. W każdym razie przed 5-tą zajdę i pójdziemy razem do „Chimery”.

10 List się nie zachował; zaproszenie (ponawiane później przez Żeromskiego) dotyczyło przyjazdu do Nałęczowa.

11 Właścicielem dóbr Pniewo w powiecie łomżyńskim był wówczas Józef Karol Jabłoński (1867-1926) - działacz społeczno-polityczny, prezes Łomżyńskiego Towarzystwa Rolniczego, od 1909 r. współwydawca „Prawdy”. W Pniewie gościli przedstawiciele kręgów literacko-artystycznych Warszawy (m.in. Franciszek Fiszer, Jan Lorentowicz), często na miesiące letnie przyjeżdżał tu Lemański (zob. J.W.Jabłoński, Wpisany w wiek zmian: pamiętnik samorzqdowca, Pniewo 2013).

12 Unum solamen (łac.) - jedna pociecha.

13 Data wpisu na bilecie wizytowym ustalona na podstawie informacji o Dziejach grzechu, wydanych na początku 1908 r. przez Gebethnera i Wolffa. Wspólna wizyta Lemańskiego i Żeromskiego w redakcji „Chimery” (wówczas mieszczącej się w Warszawie przy ul. Widok 13) też musiała nastąpić nie później niż wiosną 1908 r. - ostatni zeszyt „Chimery” nosi wprawdzie datę grudnia 1907 r., ale ukazał się prawdopodobnie dopiero w połowie 1908 r. (zob. B. Leśmian, Utwory rozproszone. Listy, oprac. J. Trznadel, Warszawa 1962, s. 308). 
Ściskam dłoń serdecznie i dla Pani załączam pozdrowienie

J. Lemański

Bilet wizytowy koloru kremowego, formatu II $\times 6,5 \mathrm{~cm}$. Na jednej stronie nadruk: Jan Lemański, na odwrocie tekst czarnym atramentem.

4.

Dziś wieczór przyjeżdżam ${ }^{\mathrm{I} 4}$, pozdrowienie

[Warszawa, 30 maja I908]

Lemański

Telegram. Adres: Żeromska / Nałęczów. Dane wysytkowe: Варшава, nr 2193/4, I7 V I908. Dane odbioru: 179 219/r [?] (cyfra pierwsza oznacza dzień, druga być może godzinę). Tekst zapisany otówkiem.

Święty Krzysztof i Tomasz, i rynek nietłumny.

Świętej Anny podziemie: kości, czaszki, trumny.

Bożnica, Żydzi, żydki, żydziaki, żydziątka -

Po Kazimierzu Wielkim niewielka pamiątka ${ }^{\text {I5 }}$.

Po obejrzeniu onej, siadłszy u Berensa ${ }^{\mathrm{I}}$,

14 Do Nałęczowa. Jak wynika z dalszych listów, Lemański przebywał w Nałęczowie do połowy lipca (mieszkał w należącej do rodziny Oktawii Żeromskiej willi „Oktawia”). Pracował tu nad wierszami, satyrami, nowelami drukowanymi tego samego lata i jesienią 1908 r. w „Literaturze i Sztuce” - kierowanym przez Lorentowicza dodatku do „Nowej Gazety”. W liście do Żeromskiego z 11 lipca 1908 r. Lorentowicz ponaglał, aby Lemański „co prędzej” przysyłał mu „manuskrypty” (BN, rkps akc. 17218, t. 22).

15 Lemański udał się na wycieczkę do Kazimierza nad Wisłą w towarzystwie Mariana Wawrzenieckiego, który prowadził wówczas badania archeologiczne w Nałęczowie i okolicy (M. Wawrzeniecki, Poszukiwania zabytków przedhistorycznych w Królestwie Polskim, „Materiały Antropologiczno-Archeologiczne i Etnograficzne" 1912, t. 12, s. 45; zob. też przypisy 32 do listu 13 i 51 do listu 18). Wymienione zabytki Kazimierza Dolnego: płaskorzeźby św. Krzysztofa i św. Tomasza na fasadzie kamienic Przybyłów (1615), wznoszących się w południowym narożu malowniczego rynku; kościół św. Anny i św. Ducha (1649-1671), w podziemiach którego znajdują się krypty; synagoga z drugiej połowy XVIII w. w stylu późnobarokowym z kamienia wapiennego.

$16 U$ Berensa - w restauracji mieszczącej się w wybudowanym przez Aleksandra Berensa w $1880 \mathrm{r}$. pierwszym w Kazimierzu hotelu, znanym pod nazwą Dom Polski lub Hotel Polski. 
Spożyliśmy to, co nam dała jego mensa.

Po czym siedliśmy w powóz, „wio” rzekli na konie

I... tu w wyobrażeniu ściskamy Wam dłonie.

Karta pocztowa, formatu $13,7 \times 9 \mathrm{~cm}, z$ czarno-biata fotografia ruin zamku; podpis: Zamek Esterki w Bochotnicy. Pod nadrukiem rękq Lemańskiego odnotowana data: Kazimierz N. W. / 7 VI o8. Na odwrocie tekst czarnym atramentem i adres: Wielmożny Pan / Stefan / Żeromski / Nałęczów / „Izba”. Stemple: Казмержъ 25 V г9о8; Наленчовъ 25 V 1908.

[Warszawa, ok. I4 lipca I908] Kochany Panie Stefanie, proszę mi wybaczyć, żem odjechał, nie pożegnawszy się z Panem. Zachodziłem nocą do izby Pańskiej ${ }^{17}$. Ale tam już panowała ciemność, rano zaś nie można było Pana budzić. Akt pożegnalny uskuteczniam za pośrednictwem niniejszego Wyczółowego Rybaka ${ }^{\mathrm{I}}$, wielce usłonecznionego. Proszę go przyjąć z życzliwością, ile że podobien jest do pewnego uczestnika kooperatywy, mawiającego częstokroć ,jucha” ${ }^{\text {I9 }}$. Upały tu afrykańskie i ciężko mi będzie z nimi walczyć, ale wyjechać musiałem ze względu na roboty zaległe. Ściskam dłoń

J. Lemański

Całemu domowi zasyłam pozdrowienie.

Karta pocztowa, formatu I4 $\times 9 \mathrm{~cm}$, z reprodukcja obrazu Leona Wyczótkowskiego; podpis: L.Wyczółkowski. Rybak / Własność Muzeum Feliksa Jasieńskiego - Naśladownictwo zastrzeżone. Nr I3 / Nakład J. Czerneckiego, Wieliczka 1907. Na odwrocie tekst czarnym atramentem i adres: Wielmożny Pan / Stefan Żeromski / Nałęczów / (g. lubelska). Stemple: Варшава, г.7.08; Наленчовъ I VII I9o8.

17 „Izba”, „chata” - jednoizbowy dom w stylu zakopiańskim, zaprojektowany przez Jana Witkiewicza (zob. przypis 20 do listu 7) i wybudowany w 1905 r. w pobliżu willi „Oktawia”, pełnił funkcję pracowni i domu letniego Żeromskiego.

18 Rybak - jeden z bardziej znanych obrazów olejnych Leona Wyczółkowskiego (1852-1936), czołowego przedstawiciela malarstwa realistycznego w Młodej Polsce. Namalowany w 1891 r., często był reprodukowany na pocztówkach.

19 Osoba nierozpoznana. Pisząc o „kooperatywie”, Lemański ma zapewne na myśli społeczne prace oświatowe prowadzone przez miejscową inteligencję przy aktywnym współudziale Żeromskiego w Nałęczowie w latach 1905-1907 i skierowane do mieszkańców Nałęczowa i okolicznych wsi lub działalność osób zaangażowanych w budowę, wyposażenie i prowadzenie ochronki (szkółki) dla dzieci pracowników uzdrowiska, współfinansowanej przez Żeromskiego i parokrotnie później w listach Lemańskiego wspominanej. Zob. m.in. Z. Żarnecka, Działalność oświatowa Faustyny Morzyckiej na tle epoki 1864-1910, Warszawa 1948; W. Nagórska, Prace konspiracyjno-oświatowe w Natęczowie w latach 1905-1907, w: Wspomnienia o Stefanie Żeromskim, zebrał i oprac. S. Eile, Warszawa 1961. 


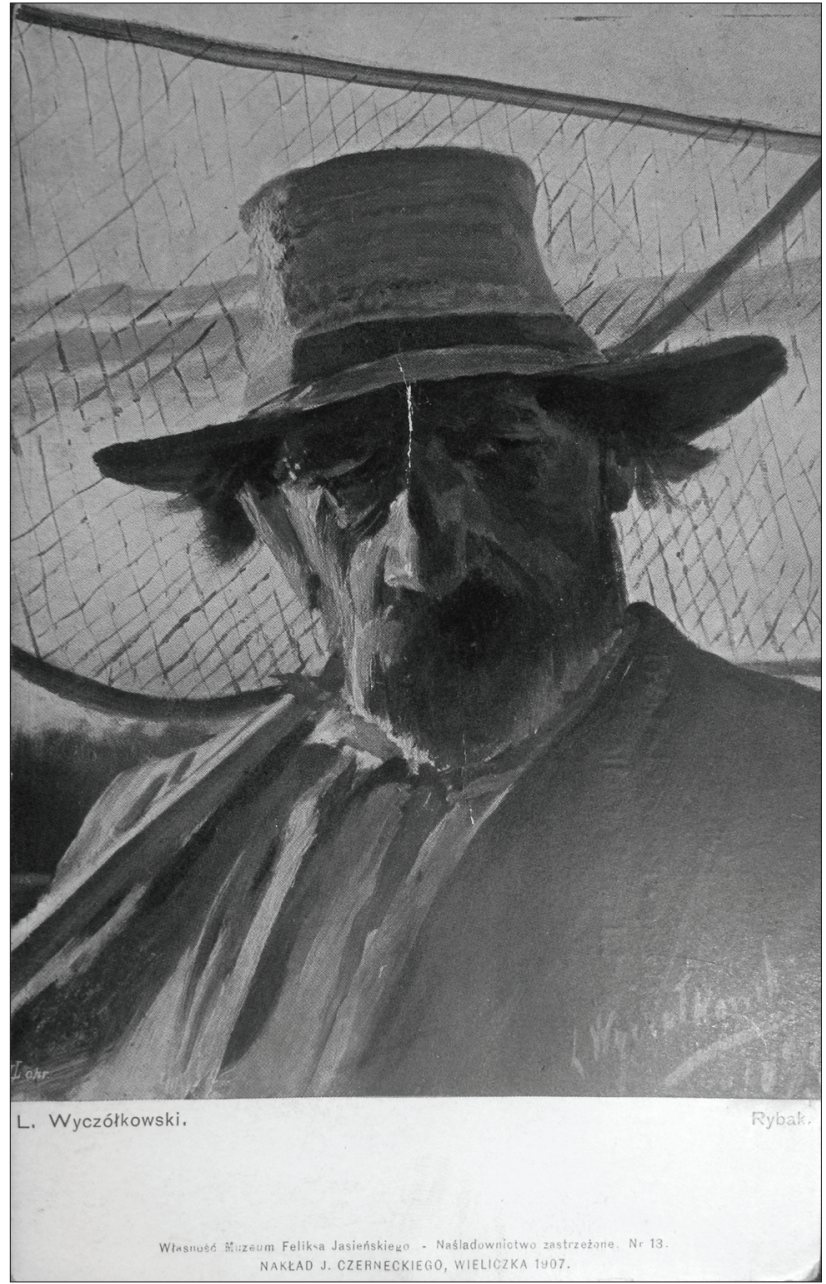

Leon Wyczółkowski, Rybak

Kochany Panie Stefanie! W tych dniach przyniósł mi pan Jan Dumę o hetmanie ${ }^{20}$. Za dar tak cenny, tak wspaniały najserdeczniej dziękuję. Prócz tej podzięki, nie mając nic innego dać w zamian, przesyłam życzenie najgorętsze, aby modlitwa hetmańska:

20 Duma o hetmanie - poemat epicki Żeromskiego, wyrosły z fascynacji pisarza postacią hetmana Stanisława Żółkiewskiego, wydany w Warszawie 1908 r. przez Kasę Przezorności i Pomocy Warszawskich Pomocników Księgarskich. Lemański otrzymał egzemplarz pierwodruku być może za pośrednictwem Jana Witkiewicza (1881-1958) - architekta, od 17 lipca 1908 r. męża Henryki Rodkiewiczówny, pasierbicy Żeromskiego. 
„Zestąp się i zrośnij w jedno, o rozszarpany polski duchu!” - została wysłuchana, i aby się „stała moc”, i aby ze związku dusz wypływało światło, i aby z jedności harmonijnej głosów rodził się hymn tryumfalny - „psalm ducha” ${ }^{\text {2I }}$. Wydana książka na ogół wzorowo. A ekslibris już zaczyna siać popłoch w muzułmanach ${ }^{22}$.

Załączam najserdeczniejsze dłoni uściski

J. Leman

Proszę pozdrowić ode mnie wszystkich miłych znajomych.

Karta pocztowa, formatu I4 $\times 9 \mathrm{~cm}$, z reprodukcja obrazu Piotra Stachiewicza; podpis: Piotr Stachiewicz. Hejnał / Naśladownictwo zastrzeżone. Nr to6 / Nakład J. Czerneckiego. Wieliczka 1908. Na odwrocie tekst czarnym atramentem $i$ adres: Wielmożny Pan / Stefan Żeromski / Nałęczów / (gub. lubelska). Stemple: Варшава, 25.7.o8; Наленчовъ 27 VII I908.

8.

[Warszawa, I8 sierpnia 1908] Kochany Panie Stefanie! Najserdeczniej dziękuję za Wasze miłe zaproszenie. Skorzystam z niego ochotnie, ale jeszcze nie zaraz. Jak tylko będę mógł, napiszę. A tymczasem posyłam Wam niniejszą Czwórkę stojącą w gotowości do wyjazdu²3. Prócz tego posyłam ukłony i pozdrowienia wszystkim miłym Oktawianom ${ }^{24}$.

Dłoń Waszą ściskam

J. Lemański

I8 VIII o8

21 Cytowane fragmenty pochodzą z Prologu: ze sceny modlitwy hetmana Żółkiewskiego przed bitwą pod Cecorą (w oryginale: „Zestąp się i zrośnij w jedno, o rozszarpany polski duchu! / Stań się Moc!”) oraz z rozdziału Widziadła snu („Wychodź, ktokolwiek mącić zamierzasz psalm ducha. / Ty, co zamącasz psalm ducha - zamącasz święty świata porządek”). Cyt. za: S. Żeromski, Pisma zebrane, red. Z. Goliński, t. 3: „Duma o hetmanie” i inne utwory epickie, oprac. Z. Goliński, Warszawa 1987, s. 108 i 133.

22 Opinię Lemańskiego o starannym wydaniu Dumy o hetmanie potwierdza Zbigniew Goliński, który przygotował edycję krytyczną tekstu i znalazł nieliczne błędy składu czy odstępstwa od autografu (ibidem, s. 258-259). Na odwrocie karty tytułowej książki wydawca - na żądanie Żeromskiego - umieścił tzw. markę ochronną, umożliwiającą autorom kontrolę nakładu: miała ona formę ekslibrisu, wykonanego przez Edwarda Okunia i przedstawiającego skrzydlatego geniusza przykutego łańcuchami do ziemi.

23 Mowa o umieszczonej na stronie licowej pocztówki reprodukcji mniej znanego obrazu olejnego Józefa Chełmońskiego pt. Czwoórka, namalowanego w 1879 r. Obraz figuruje w bazie strat wojennych Ministerstwa Kultury i Dziedzictwa Narodowego.

24 Oktawianie - rodzina, goście i stali bywalcy willi „Oktawia”, wybudowanej w 1880 r. przez Konrada Chmielewskiego, ojczyma Oktawii z Radziwiłłowiczów, $1^{\circ}$ v. Rodkiewiczowej (1862-1928) - od 1892 r. żony Żeromskiego. 
Karta pocztowa, formatu I4 $\times 8,8 \mathrm{~cm}$, z reprodukcja obrazu Józefa Chetmońskiego Czwórka. Na odwrocie tekst czarnym atramentem i adres: Wielmożny / Stefan Żeromski / Nałęczów / (g. lubelska). Datownik poczty warszawskiej uszkodzony wskutek oddarcia znaczka; datownik natęczowski: 6 VIII 1908.

9.

Kochany Panie Stefanie!

[Warszawa, 5 stycznia 1909]

Z okazji Nowego Roku przesyłam Panu najserdeczniejsze życzenia wszystkiego dobrego. Żal mi, że nie mogę ich wypowiedzieć osobiście i ujrzeć Pana na tle zakopiańskich ośnieżeñ ${ }^{25}$. Dobrze jest do swego bliźniego czasem coś napisać. Najserdeczniej pozdrawiam Panią i Adasia.

J. Lemański

$$
5 \mathrm{I} \text { o9 }
$$

Karta pocztowa, formatu $14,4 \times 9 \mathrm{~cm}$, przedstawiająca kobietę w stylizowanym stroju ludowym na tle ornamentu, sygnowana: Jurgielewicz. Podpis: Nakładem Warszawskiej Szkoły Sztuk Pięknych / Доз. Цен. Bap. 16/5 1905 r. / Tow. Akc. S. Orgelbranda S-ów w Warszawie. Na odwrocie tekst czarnym atramentem i adres: Wielmożny / Stefan Żeromski / Zakopane. Czytelny tylko datownik poczty warszawskiej: 25.12.08.

Kochany Adasiu!

Posyłam Ci w upominku to, co najbardziej wymyślić można miłego. Uściskaj i ucałuj ode mnie oryginał tego wizerunku ${ }^{26}$ i mamę pozdrów.

Twój Jan Lemański

Karta pocztowa, formatu $13,7 \times 8,7 \mathrm{~cm}, z$ czarno-biata fotografia przedstawiajaca Żeromskiego i nadrukowanym przez wydawce podpisem: Stefan Żeromski. Na odwrocie tekst czarnym atramentem i adres: Wielmożny / Adam Żeromski / ulica Zamojskiego, willa Polanka / Zakopane / Austria Galicja. Stempel: Варшава, г9.or.o9.

25 Po aresztowaniu w nocy z 25 na 26 października 1908 r. Żeromski został zmuszony przez władze carskie do opuszczenia Królestwa. Powodem była jego działalność społeczno-oświatowa w Nałęczowie w latach 1905-1907. Z końcem roku wyjechał z żoną i synem Adasiem (1899-1918) do Zakopanego.

26 Zob. metryczka karty pocztowej poniżej. 
[Warszawa, 6 lutego I909] ${ }^{27}$

Warszawa, 6 I I9o9

Kochany Panie Stefanie!

Najserdeczniej dziękuję za Wasz miły list i za pamięć o mnie. Stanowisko, które mi proponujecie, gotów jestem przyjąć i ufam, że mu odpowiem dobrze ${ }^{28}$. Horoskop ten jeśliby się ziścił, niezmiernie byłbym szczęśliwy, ile że od dawna pragnąłem dłużej pomieszkać w Krakowie. Bądźcie łaskawi napisać, kiedy miałaby się odbyć moja inwestytura? Przyślijcie mi, proszę, cokolwiek bliższych danych o tej sprawie.

Podobno Państwo macie zamiar (słowa są Witkiewicza ${ }^{29}$ ) obrać na stalszy pobyt Kraków? Udzielcie mi wiadomości i o tym, bardzo Was o to proszę. W oczekiwaniu odpowiedzi przesyłam Wam najserdeczniejszy uścisk i pozdrowienie dla Pani i dla Adasia.

Wasz

J. Lemański

Dwukartkowy arkusik cienkiego kremowego papieru listowego ze znakiem wodnym, formatu 25,4 × 20,4 cm. Tekst czarnym atramentem na k. Ir i iv. Koperty brak.

12.

Per che sta in silentio il Vostro $3^{30}$

[Warszawa, luty I909]

J.L.

Karta pocztowa, formatu $13,7 \times 9 \mathrm{~cm}$, z rysunkiem lwa (seria znaków zodiaku) i litera ¿ jako symbolem zodiakalnego lwa; podpis: Juillet. Le lion / Dietrich \& C $\underline{\mathrm{ie}}$ Editeurs

$27 \mathrm{~W}$ autografie listu wyraźna data styczniowa, ale z korespondencji Żeromskiego wynika, że Lemański odpowiadał na list pisarza z 4 lutego 1909 r. (zob. S. Żeromski, Pisma zebrane, red. Z. Goliński, t. 37: Listy 1905-1912, oprac. Z.J. Adamczyk, Warszawa 2006, s. 129). Zapis daty miesięcznej „I” to prawdopodobnie pomyłka Lemańskiego.

28 W liście z 4 lutego 1909 r. Żeromski proponował Lemańskiemu stanowisko sekretarza tworzącego się w Zakopanem (przy aktywnym współudziale Żeromskiego) Towarzystwa Pisarzy Polskich (zob. ibidem, s. 129-130; J.W. Lemański, Listy Stefana Żeromskiego do Jana Lemańskiego o Towarzystwie Literatów Polskich, „Kurier Literacko-Naukowy” 1935, nr 48). Nie wiadomo dlaczego Lemański - mimo udzielonej zgody - sekretarzem nie został (obowiązki te pełnił Stanisław Wyrzykowski), wszedł natomiast do jedenastoosobowego Wydziału Towarzystwa.

29 Chodzi o Jana Witkiewicza.

30 Per che sta in silentio il Vostro (właśc. Perché sta in silenzio il Vostro, wł.) - 'Czemu milczy Wasz' (w domyśle oraz zgodnie z symbolami i rysunkami na karcie: lew). 
Bruxelles. Tekst czarnym atramentem na stronie licowej, pod rysunkiem lwa i obok litery ภ. Na odwrocie adres: Wielmożny Pan / Stefan Żeromski / Zakopane / „Polanka”. Na warszawskich stemplach pocztowych zamazana data dzienna (być może 7), czytelne daty miesięczna i roczna: 2.09 .

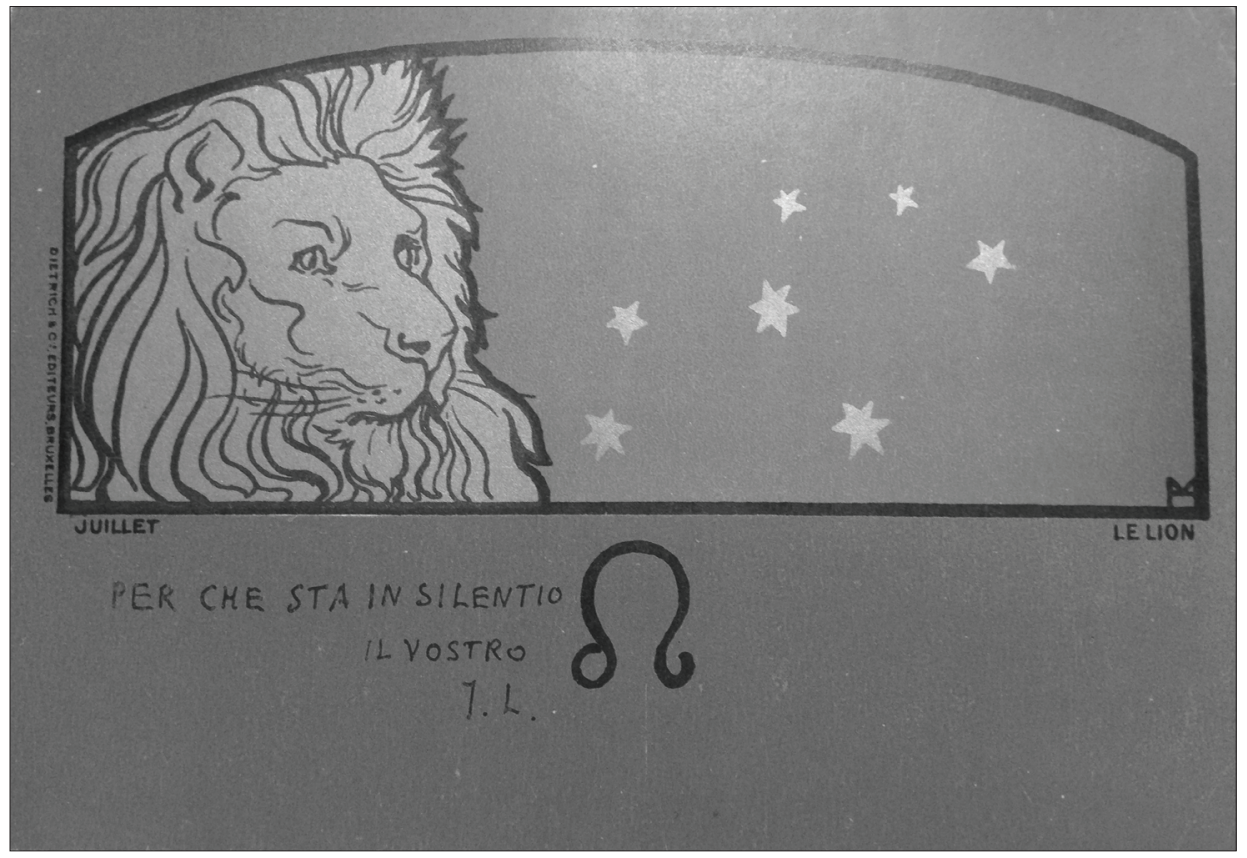

Juillet. Le lion

Kochany i Szanowny Panie Stefanie!

Warszawa, 29 III [19]o9

Najserdeczniej dziękuję Wam za miły list czterostronnicowy ${ }^{3 \mathrm{I}}$. Za to posyłam Wam najpiękniejszą kartę, jeżeli nie ostatnich czasów, to przynajmniej jednę z najładniejszych rzeczy Wawrzyńca ${ }^{32}$. Dziwnym trafem ilustruje epizod z Popiotów.

31 List z 16 marca 1909 r., w którym Żeromski - przepraszając za długie milczenie - udzielił Lemańskiemu szczegółowych informacji na temat zebrania założycielskiego Towarzystwa Pisarzy Polskich w Zakopanem 14 marca (S. Żeromski, Pisma zebrane, red. Z. Goliński, t. 37: Listy 1905-1912, op. cit., s. 136-137).

32 Warwrzyniec - Marian Wawrzeniecki (1863-1943), malarz, archeolog, grafik „Chimery”, chętnie nawiązujący w swoich obrazach do kultury słowiańskiej. Jego dzieła często pojawiały się na kartkach i znaczkach pocztowych; na przesłanej Żeromskiemu i podpisanej Ballada widnieje dziewczyna rzucająca się ze skalnego urwiska do wody oraz próbujący ją zatrzymać młodzieniec - obraz skojarzony chyba przez Lemańskiego ze sceną śmierci Heleny w Popiotach. 
Co do sprawy onego sekretarstwa, oby się ułożyło wszystko wedle Waszych przewidywań, bardzo tego pragnę. Najmilszą dla mnie rzeczą będzie Wasza zapowiedź mieszkania w Krakowie.

Ściskam Was najserdeczniej i pozdrawiam Panią. Przesyłam pocałunek Adasiowi, który teraz ma, szczęśliwiec, żywy kinematograf z prawdziwego morza ${ }^{33}$.

J. Lemański

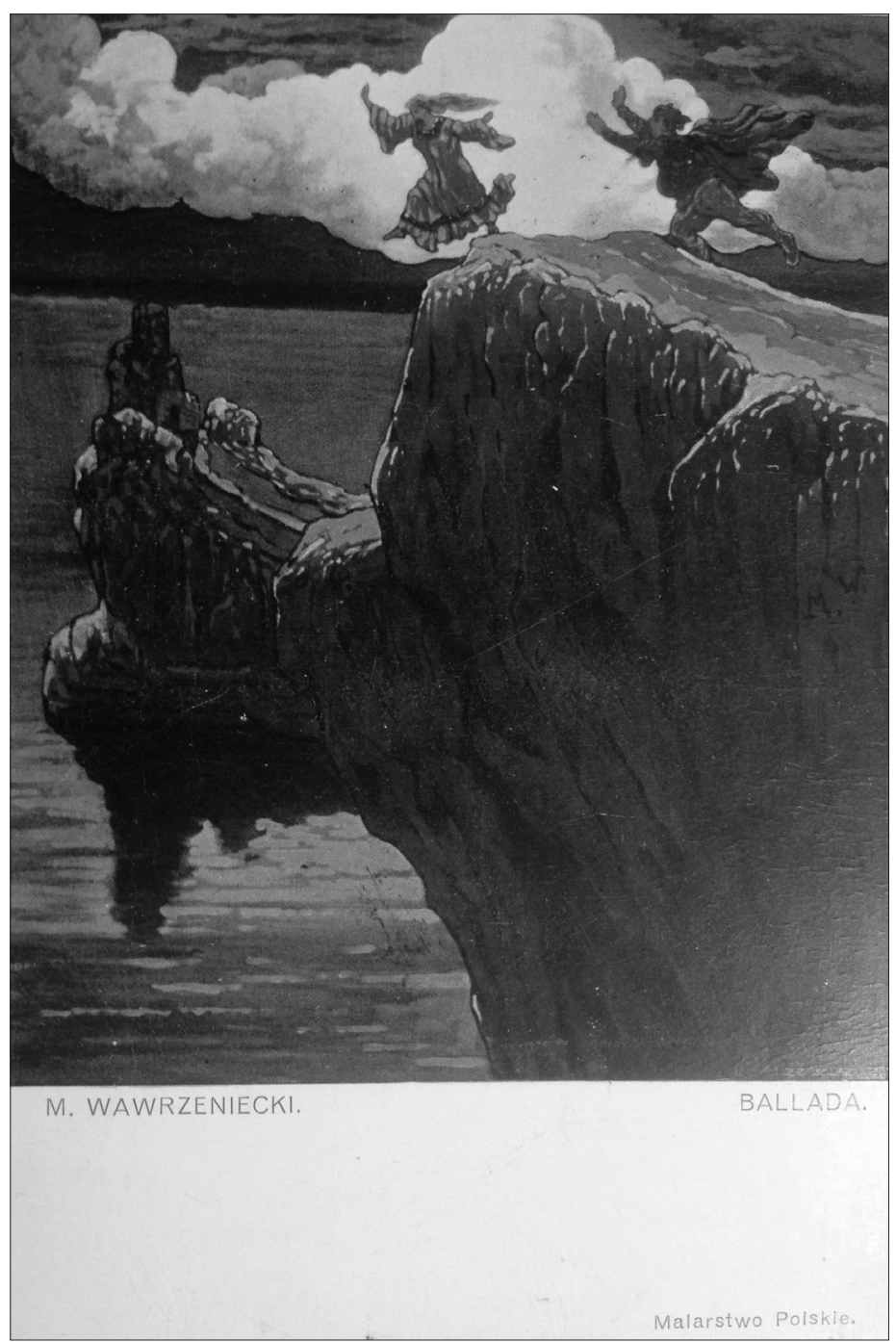

Marian Wawrzeniecki, Ballada

33 W drugiej połowie marca 1909 r. Żeromscy wyjechali nad Morze Adriatyckie, do Lovrany pod Abbazią. Przebywali tam sześć tygodni. 
Karta pocztowa, formatu I4 $\times 9 \mathrm{~cm}$, z reprodukcjq obrazu Mariana Wawrzenieckiego; podpis: M. Wawrzeniecki. Ballada / Malarstwo Polskie. Na odwrocie tekst czarnym atramentem i adres: Wielmożny Pan / Stefan Żeromski / Pension Central / Lovrano / bei Abbazia. Stemple poczty warszarwskiej: 17.3.09.

\section{4.}

[Warszawa, I4 kwietnia I909]

Panie Stefanie Szanowny, Kochany!

Jedzie ninie[j]szy jeździec do Lovrany,

Aby ode mnie złożyć Wam życzenia:

Niechaj się spełnią wszystkie Wasze chcenia.

Życzy Wam zdrowia i groszy bez liku

Ten parobeczek na wronym koniku.

Ten parobeczek na koniku wronym

Życzyć Wam szczęścia jest upoważniony.

Przyjmijcie parobeczka sercem radem:

Jakże mi żal jest, że sam tam nie jadę!

Taka już widać kalkulacja Boża.

Ściskam Was. Ukłon załączam dla morza.

J. Lemański

I4 IV o9

Życzenia Pani oraz Adasiowi

Mój ambasador również niech wysłowi.

Kiedy nad morzem spacerujesz z mamą,

Pamiętaj o mnie też, Caro Adamo ${ }^{34}$ !

Karta pocztowa, formatu I4,6 9 cm, przedstawiająca mężczyzne w stroju ludowym na czarnym koniu i na tle ornamentu, sygnowana: Jurgielewicz. Podpis: Nakładem Warszawskiej Szkoły Sztuk Pięknych / Доз. Цен. Вap. 16/5 I905 r. / Tow. Akc. S. Orgelbranda S-ów w Warszawie. Na odwrocie tekst czarnym atramentem i adres: Wielmożny / Stefan Żeromski / Pensione Centrale / Lovrano / (bei Abbazia). Stemple poczty warszawskiej: I.4.09. 


\section{Szanowny i Drogi Panie Stefanie!}

[Pniewo] 24 VI [I9]o9

Ostatnia karta Wasza ${ }^{35}$ napełniła mię niewymowną radością. Jako człek wdzięczny posyłam niniejszą Orkę Wyczóła ${ }^{36}$. Kiedy będziecie nad morzem, zróbcie mi tę łaskę i przyszlijcie swój morski adres, abych Wam jeszcze insze piękne karty mógł pisać.

Serdeczny uścisk załączam

Jan Lemański

\section{Pniewo p. Łomżę}

Karta pocztowa, formatu I4 × $9 \mathrm{~cm}$, z reprodukcja obrazu Leona Wyczótkowskiego; podpis: L. Wyczółkowski. Orka na Ukrainie. Na odwrocie tekst czarnym atramentem i adres: Wielmożny Pan / Stefan Żeromski / Kraków / ul. Loretańska 4 (Pensjonat „Podole”). Adres przekreślony czarnym atramentem i obcq rękq dopisane: Zakopane / ul. Jagiellońska. Dom dra Brzezińskiego. Na datownikach tomżyńskich czytelna tylko data dzienna I4 i roczna o9.

\section{6.}

\section{Kochany Panie Stefanie!}

Podpisałem List otwarty w sprawie sprowadzenia zwtok Juliusza Stowackiego i jednocześnie odsyłam ${ }^{37}$. Ale ośmieliłbym się zrobić przy tym kilka uwag, a mianowicie.

35 Karta nie zachowała się.

36 Orka na Ukrainie - słynny obraz olejny Leona Wyczółkowskiego z 1892 r., często reprodukowany na kartach pocztowych.

37 List otwarty w sprawie sprowadzenia zwtok Juliusza Stowackiego napisał Żeromski w Paryżu pod koniec listopada 1909 r. Przedstawiał w nim historię bezowocnych starań powołanego w Krakowie wiosną 1909 r. Komitetu Obywatelskiego dla Sprowadzenia Zwłok Słowackiego (Zeromski był jego członkiem) o przeniesienie prochów poety do krypty na Wawelu. Kategoryczny sprzeciw wobec pochówku Słowackiego na Wawelu wyraził kardynał Jan Puzyna (1842-1911; biogram w PSB, t. 29) - biskup diecezjalny krakowski w latach 1895-1911. List otwarty powstał z inicjatywy Polaków przebywających jesienią 1909 r. w Paryżu (m.in. Artura Górskiego, Jana Hempla, Bronisława Piłsudskiego, Andrzeja Struga), którzy na zebraniu zwołanym 19 listopada 1909 r. postanowili zwrócić się do społeczeństwa polskiego z dawnym pomysłem (m.in. Henryka Sienkiewicza i Stanisława Witkiewicza) uroczystego pochowania Słowackiego w Tatrach. Tekst Listu otwartego wysłany został do 112 pisarzy, artystów, ludzi nauki i działaczy społecznych z prośbą o podpisanie i odesłanie na adres Hempla (sekretarza paryskiego zebrania). Lemański List otwarty podpisał (jego nazwisko widnieje pod tekstem Listu, opublikowanym w lutym 1910 r. w wielu czasopismach krajowych) i odesłał na adres Żeromskiego, dołączając do przesyłki prywatny list, w którym wyjaśniał własne stanowisko w tej kwestii (zob. m.in. Sprawa sprowadzenia do kraju prochów Juliusza Stowackiego w roku 1909: 
Dobrym jest zamiar przeniesienia kości Słowackiego do groty w Tatrach na s t ałe, lecz jeżeli to ma być na tymczasem, będzie to wyglądało, jak gdybyśmy wysyłali Słowackiego po śmierci w góry dla poratowania zdrowia, którego mu nie daliśmy, kiedy żył.

Słowacki w Paryżu, w tym kochanym przez siebie miasteczku, najniezawodniej czuje się po śmierci stokroć lepiej, niżby mu było w zimnej skale Tatr leżeć osamotnionemu albo nawet w podziemiach wawelskich, tuż obok swego antagonisty Mickiewicza $^{3^{8}}$, który może byłby temu wraz z ks. biskupem Puzyną przeciwny.

Zresztą, pozbawiać Paryż Słowackiego, byłoby to zmniejszać atrakcję tego miasta, które dla nas, Polaków, nawet żywych, tak miłym jest schronieniem.

Po co? Niechby sobie tam spoczywał i niechby ściągał Polaków tak, jak to robi Shelley w Rzymie i Keats w stosunku do Anglików ${ }^{39}$.

Puzyna nie jest wieczny - i nawet bardzo niewieczny. Gdy zemrze, można będzie i o Wawelu pomyśleć. A tymczasem na co te wszystkie demonstracje, wyglądające tak, jakbyśmy ze zwłok Słowackiego chcieli robić taran przeciwko ks. Puzynie?40 Zły duch (przykro nam, że uosobiony teraz w ks. biskupie) zwalcza się przez ducha dobrego, a nie przez robienie temu złemu duchowi na złość. Wszakże sama odezwa mieści zwrot: „Ks. biskup krakowski mocą nadanej mu władzy rozstrzyga nieodwołalnie o podziemiach Wawelu"4I. Ks. biskup rozstrzyga o podziemiach. Ks. biskup jest panem podziemnym. Któż mu nadał tę władzę? My sami, my - panujący nadziemsko. I powinniśmy uznać tę podziemną władzę biskupią za prawowicie przez nas ustanowioną i nie powinniśmy przeciwko temu gwałtować.

1. J. Zborowski, S. Żeromski i Akademicki Komitet dla Sprowadzenia Zwtok Stowackiego do Kraju, 2. S. Pigoń, Zabiegi o wzniesienie Stowackiemu grobowca w Tatrach, w: Miscellanea z pogranicza XIX i XX wieku, red. S. Pigoń, „Archiwum Literackie”, t. 8, Wrocław-Warszawa-Kraków 1964, s. 425-466; S. Żeromski, Pisma zebrane, red. Z. Goliński, kontynuacja red. Z.J. Adamczyk, t. 25, Publicystyka 1889-1919, oprac. Z.J. Adamczyk, Warszawa-Kielce 2016, s. 149-165).

38 Juliusz Słowacki (1809-1849; biogram w PSB, t. 39) zmarł 3 kwietnia 1849 r. w Paryżu, pochowany został dwa dni później na cmentarzu Montmartre. Adam Mickiewicz (1798-1855; biogram w PSB, t. 20) zmarł 26 listopada 1855 r. w Konstantynopolu, jego zwłoki przewieziono do Paryża i pochowano na cmentarzu Montmorency 21 stycznia 1856 r. Prochy autora Pana Tadeusza sprowadzono do kraju i uroczyście złożono na Wawelu 4 lipca $1890 \mathrm{r}$.

39 Percy Bysshe Shelley (1792-1822) i John Keats (1795-1821) - wybitni angielscy poeci doby romantyzmu. Obaj zmarli we Włoszech i zostali pochowani na cmentarzu protestanckim w Rzymie.

40 Sprzeciw kardynała Puzyny wobec pochówku Słowackiego na Wawelu został nagłośniony przez prasę i wywołał ostre protesty publicystów i środowisk akademickich. W maju i czerwcu 1909 r. odbyły się liczne zebrania, wiece i demonstracje polskich studentów we Lwowie, Terespolu, Fryburgu, Paryżu, Krakowie (tu zakończone zamieszkami i starciami z policją). Zob. S. Żeromski, Pisma zebrane, red. Z. Goliński, kontynuacja red. Z.J. Adamczyk, t. 25: Publicystyka 1889-1919, op. cit., s. $149-151$.

41 W ostatecznej wersji Listu otwartego: „Książę biskup krakowski mocą nadanej mu władzy rozstrzyga nieodwołalnie o katedrze i podziemiach Wawelu" (cyt. za: ibidem, s. 152). 
My, czciciele swobody, swobody Króla-Ducha ${ }^{42}$, powinniśmy uznać jej liberum veto nawet podziemne, nawet biskupie. Dopóki ks. Puzyna jest jednym z Polaków, choćby tylko jednym, musimy jego władzę, którąśmy sami jemu nadali, szanować. Albo musimy zrobić tak, aby ta władza do nas wróciła; musimy zrobić tak, abyśmy my, walczący pod sztandarem Słowackiego, uosabiali nie jego prochy podziemne, ale jego nadziemską, królewską potęgę Ducha, któremu przecież nie chodzi, aby koniecznie był internowanym czy to na Wawelu, czy w grocie tatrzańskiej. Król-Duch tak samo jak nie trzeba, aby pukał w podwoje lochów wawelskich i ubiegał się o pobyt tam za zezwoleniem ks. biskupa Puzyny, Król-Duch tak samo również niekoniecznie musi na złość ks. biskupowi osiedlać się w Tatrach.

Dobrze mu jest na Montmartrze. Niech sobie tam mieszka w spokoju i niech czeka tych dobrych czasów, kiedy naród tak zjednomyślnieje, że właśnie ta sama jednomyślność będzie dla Króla-Ducha Słowackiego nie tymczasowym i przemijającym, jeno trwałym i najgodniejszym jego przybytkiem.

Podpisałem odezwę, żeby się nie wyłączać od uchwały Komitetu Obywatelskiego, ale projektu jego nie uważam za najlepszy i jedyny, i niewywołujący w nas rozdwojeń.

W zakończeniu odezwy tej powiedziano, że wielki poeta „wpośród ponurej (?) zimy i czarującej pogody będzie błogosławił niziny"43. Poecie więc nadany jest przez odezwę rys niezmiennej, błogosławiącej pogody ducha, na którą nie wpływa ni ponurość (?) zimy, ani czarująca pogoda. On zawsze błogosławi nizinom. Dobrze. Ale czemuż my, poety czciciele, nie mamy być tak samo pogodni i czemu nie mamy błogosławić nawet nizinom ks. biskupa Puzyny?... I czemuż nie mamy wierzyć w to, że kiedyś nizina ta będzie mogła wznieść się do uczczenia i do przyjęcia w siebie Króla-Ducha?

Ufajmy i wierzmy.

„Jeżelibyście - mów[i] św. Łukasz, XVII, 6 - mieli wiarę jako ziarno gorczyczne, rzeczcie temu drzewu morwowemu: wykorzeń się a przesadź się w morze, a usłucha was" ${ }^{44}$. Tak samo wierzmy, że przyjdzie czas, iż będziemy mogli rzec

42 Aluzja do poematu Słowackiego pod takim tytułem, pisanego w latach 1845-1849 i stanowiącego podsumowanie poglądów historiozoficznych poety.

43 Fragment pochodzi z przedostatniego zdania Listu otwartego: „Wierzymy, że tak postawiwszy i przeprowadziwszy sprawę, oddamy najdostojniejszy i powszechny hołd prochom wielkiego Poety, wyjmiemy czcigodne jego imię spod czyjejkolwiek w narodzie niełaski, wmurujemy jego kości w dzikie ściany naszej ojczyzny, gdzie wichrem otoczony, owiany mgłami, wpośród ponurej zimy i czarującej pogody będzie błogosławił niziny" (ibidem, s. 154). Lemański, krytykując nie tylko pomysł przeniesienia prochów Słowackiego do groty w Tatrach, ale także styl Listu, chyba nie wiedział, że jego autorem jest Żeromski.

44 Cytat z Ewangelii wg śr. Eukasza (17,6); w przekładzie Jakuba Wujka: „A Pan rzekł: Jeźlibyście mieli wiarę jako ziarno gorczyczne, rzeczecie temu drzewu morwowemu: Wykorzeń się a przesadź się w morze, a usłucha was". 
ks. biskupowi Puzynie: wykorzeń się sprzed wrót Wawelu i precz odejdź, a usłucha nas i precz odejdzie, i zginie jego moc podziemna, i upadnie wobec nadziemskiej potęgi Króla-Ducha ${ }^{45}$.

Ściskam Was najserdeczniej

Jan Lemański

Napiszcie słów kilkoro, co porabiacie.

Dwa dwukartkowe arkusiki cienkiego kremowego papieru, formatu $28 \times 2 I, 5 \mathrm{~cm}$. Tekst czarnym atramentem na k. Ir, 2r, 3ri 4r. W prawym górnym rogu kart 2-4 foliacja obca ręka, czerwonq kredkq. Koperty brak.

Druk (zmieniony i skrócony) w: S. Pigon, Zabiegi o wzniesienie Słowackiemu grobowca w Tatrach, op. cit., s. 459-46I.

[Warszawa, ok. 22 czerwca I9ı。]

Szanowny i Kochany Panie Stefanie!

Pani Ewa Lorentowiczowa ${ }^{46}$ pisze mi, że ofiarujecie mi swoje mieszkanie ${ }^{47}$. Jest wiadomość ta dla mnie tak nieprawdopodobnie miła jak baśń. Najserdeczniej Wam za ten pomysł dziękuję. Wybieram się do morza i chętnie zatrzymałbym się w Paryżu w tych przyjaznych warunkach. Napiszcie mi z łaski swojej kilka słów na temat tych formalności mieszkaniowych, tj. do kogo się mam zgłosić, gdybyście Państwo już wyjechali etc.

Najserdeczniejsze pozdrowienie dla obojga Państwa i dla Adasia łączę.

Św. Barbary $12^{4^{8}}$

Jan Lemański

Karta pocztowa, formatu I4 $\times 9 \mathrm{~cm}$, z reprodukcja obrazu Stanistawa Fabijańskiego; podpis: St. Fabijański. Skarbiec królewski / Z cyklu: Wawel. Na odwrocie tekst

45 Przepowiednie Lemańskiego spełniły się w 1927 r. - z inicjatywy marszałka Józefa Piłsudskiego prochy Słowackiego zostały sprowadzone do kraju i 28 czerwca spoczęły w krypcie królewskiej na Wawelu.

46 Ewa z Rościszewskich Lorentowiczowa (1873-1944) - malarka, introligatorka, studentka Académie Colarossi w Paryżu, od 1903 r. żona Jana Lorentowicza (1868-1940; biogram w PSB, t. 17) - znanego krytyka teatralnego i publicysty, utrzymującego przyjazne stosunki m.in. z Lemańskim, Przesmyckim, Reymontem, Żeromskim.

47 Wynajmowane przez Żeromskich paryskie mieszkanie przy rue Ernest Cresson 22. Pisarz mógł je udostępnić Lemańskiemu, bo na całe lato wyjeżdżał z rodziną do nadmorskiej miejscowości Ploumanach w Bretanii.

48 Adres warszawski Lemańskiego. 
czarnym atramentem i adres: Wielmożny Pan / Stefan Żeromski / Paris / 22 rue Ernest Cresson 22 / (I4 Arrond). Adres przekreślony czarnym atramentem i obca rękq dopisane: Badet Hôtel des Rochers / à Ploumanach / près Perros Guirec / Côtes du Nord. Datownik poczty Perros Guirec nieczytelny; datowniki warszawwskie: 9.6.Io.

18.

[Warszawa] 3 VII i9io

Szanowna Pani! Najserdeczniej dziękuję za taki miły i taki przyjazny list ${ }^{49}$, który mi tyle rzeczy zasnutych mgłami oddalenia przypomniał! Nałęczów, bzy, słowiki, majowe rana, wieczorne posiedzenia na werandzie, Daniłowskiego zaspanośćs ${ }^{5}$, Wawrzenieckiego wykopaliskowanie ${ }^{51}$, babci ,jaźminy” $5^{2}$, p. Stefana krzątanie się koło ochrony i tyle innych wspomnień, które teraz nasuwają mi się przed oczy. Za elektryczne mieszkanie Państwa najserdeczniej dziękuję. W Paryżu będę około $20 \mathrm{bm}$., a potem - ocean ${ }^{53}$. Na jego brzegach pragnąłbym z Państwem się zobaczyć.

49 Listy Oktawii Żeromskiej i późniejsze karty Żeromskiego do Lemańskiego nie są znane.

50 Gustaw Daniłowski (1871-1927; biogram w PSB, t. 4) - pisarz, publicysta, działacz socjalistyczny, blisko związany z Żeromskim w latach 1904-1906, gdy przemieszkiwał z rodziną w Nałęczowie (również w willi „Oktawia”) i mocno angażował się w prowadzone tam akcje społeczno-oświatowe. Przyjacielskie stosunki utrzymywali do 1909 r. (zob. G. Legutko, Niespokojny ptomień. Życie i twórczość Gustawa Danitowskiego, Kielce 2011, s. 143-145). „Zaspaność” Daniłowskiego była chyba anegdotyczna - Walentyna Nagórska, działaczka utworzonego w Nałęczowie Towarzystwa "Światło”, wspomina: „Żeromski musiał widywać się z nim często i później mawiał o tych wizytach żartobliwie: «Ach, jak długo zwykle wyczekiwałem na Daniłowskiego, który pisywał po nocach, w dzień zaś sypiał do obiadu"” (cyt. za: Wspomnienia o Stefanie Żeromskim, zebrał E.L. Migasiński, Warszawa 1927, s. 41).

51 W szkicu Poszukiwania zabytków przedhistorycznych w Królestwie Polskim (op. cit.) Wawrzeniecki wspomina, że jesienią 1907 r. został listownie powiadomiony przez mecenasa Wacława Łypacewicza o odkryciu zabytków neolitycznych podczas kopania fundamentów pod jego dom w Nałęczowie; na podobne znaleziska natrafił w tym czasie również Żeromski. Wiosną 1908 r. Wawrzeniecki uzyskał z Kasy im. Józefa Mianowskiego dofinansowanie badań i 1 czerwca przyjechał do Nałęczowa na zaproszenie Żeromskiego. Przez dziewięć dni mieszkał w willi „Oktawia”i prowadził badania archeologiczne, w których - w rolach obserwatorów - uczestniczyli m.in. Lemański i Żeromski. Naukową relację $\mathrm{z}$ tych prac przedstawił Wawrzeniecki we wspomnianym artykule. W zbiorach BN (rkps akc. 17 218, t. 40) zachowała się kartka pocztowa Wawrzenieckiego do Żeromskiego z 8 lipca 1908 r., z podziękowaniem za gościnę oraz zdjęcia naczyń ceramicznych, wydobytych przez Żeromskiego na terenie willi Łypacewicza i przekazanych przez niego do Muzeum Przemysłu i Rolnictwa w Warszawie. Zob. też W. Borowy, Marian Wawrzeniecki, w: idem, O Żeromskim. Rozmowy i szkice, op. cit., s. $277-284$.

52 Zapewne matka Oktawii Żeromskiej - Oktawia z Medunieckich Chmielewska, $1^{\circ}$ v. Radziwiłłowiczowa (1838-1920), w listach pisarza do żony też nazywana „babcią” (wskazywałyby na nią również kresowe ,jaźminy"/,jaśminy” - Oktawia Chmielewska wiele lat spędziła na Wileńszczyźnie).

53 Po krótkim pobycie w Paryżu Lemański planował przyjazd do Bretanii, a następnie do Włoch (plan tej podróży przedstawił w liście do przyjaciela, malarza Stanisława Masłowskiego z 9 lipca 1910 r.: 
Proszę ode mnie pozdrowić bardzo gorąco p. Stefana i Adasia i przyjąć zapewnienia mego przywiązania i szacunku

Karta pocztowa, formatu I4 $\times 9 \mathrm{~cm}$, z reprodukcja obrazu Arnolda Böcklina; podpis: A. Böcklin, L'Ermite. Na odwrocie tekst czarnym atramentem i adres: Madame / Oktawia Żeromska / Hôtel des Rochers / France. Côtes du Nord / Ploumanach près Perros Guirec. Stempel: Варшава, 2o.6.Iо.

Warszawa, ig VII I910 Szanowna Pani! Przygotowania moje do podróży tak dalece postąpiły, że już za tydzień spodziewam się być w Paryżu. Noszę przy sobie Pani miły, serdeczny list i odczytując go, mam wrażenie takie, jakbym już był przy Was blisko. Dobre to były czasy, kiedy oddawaliśmy się truskawkożerstwu przy chacie, albo kiedyśmy uczestniczyli w pracach nad utwierdzeniem muru przy ochronie ${ }^{54}$, albo kiedy Janek $^{55} \mathrm{z}$ Adasiem prowadzili wieczorne rozmowy, w których ten pierwszy, niepomny na męską powagę, dopuszczał się dzieciństwa, a drugi, wbrew swemu płochemu wiekowi, stawał się dojrzałym sensatem. Proszę ucałować ode mnie tegoż męża, jako też jego dni twórcę. Z Paryża napisać nie omieszkam -

J. Lemański

Karta pocztowa, formatu $14 \times 9 \mathrm{~cm}$, z reprodukcja obrazu Wojciecha Weissa; podpis: Wojciech Weiss, Okno - La fenêtre. Na odwrocie tekst czarnym atramentem $i$ adres: Wielmożna Pani / Oktawia Żeromska / Hôtel des Rochers / Ploumanach / près Perros Guirec / France. Côtes du Nord. Czytelny tylko stempel: Варшава, 6.7.ı.

"Ja niedługo już wyruszam, in primis - do Krakowa dla załatwienia spraw wydawniczych, a potem do Paryża, gdzie również mam pewien nie tylko podróżniczy cel. Z Paryża może pojadę do Bretanii. Ten plan nie wyklucza, że może się znajdę we Włoszech", Korespondencja Stanistawa Mastowskiego, BN, rkps 7266, k. 16).

54 Budowę ochronki, zaprojektowanej przez Witkiewicza i pod jego nadzorem stawianej, ukończono 19 lipca 1907 r. Koszt budowy był znaczny i pokrywany albo ze zbiórek społecznych, albo przez Żeromskiego, część prac wykonywano samodzielnie (zob. m.in. S. Butrym, Budowa i dzieje ochronki im. Adama Żeromskiego w Natęczowie, w: Muzeum Stefana Żeromskiego w Natęczowie, przedmowa I. Iskrzycka, słowo wstępne F. Araszkiewicz, Nałęczów [b.r.], s. 30-36).

55 Chodzi o Jana Witkiewicza. 


\section{Szanowna Pani}

Lago Maggiore Pallanza

Hotel Eden

23 IX I9I0

Najserdeczniejsze pozdrowienie przesyłam. Drugą kartę posłałem pod adresem morskim. Do Paryża nie wybrałem się dotąd, ale się wybieram. O ile Szanowni Państwo już do domu wrócili, proszę o słówko wiadomości.

Pozdrowienie dla wszystkich załączam

J. Lemański

Karta pocztowa, formatu I4 $\times 9 \mathrm{~cm}, z$ czarno-biatym zdjeciem jeziora Maggiore i wyspy Bella; podpis: Isola Bella - Lago Maggiore. Na odwrocie tekst czarnym atramentem i adres: Wielmożna Pani / Oktawia Żeromska / rue Ernest-Cresson 22 / Paris. Adres przekreślony czarnym atramentem i obca rękq dopisane: Hôtel de France / à Quiberon / Morbihan. Stemple: Locarno 23 SET. ro; Quiberon 25.9.Io.

Kochany Panie Stefanie!

Lago Maggiore Pallanza

Hotel Eden

[ok. 30 września I9ıo]

Najserdeczniej dziękuję za kartę. Z tych pięknych stron, których widok przesyłam, muszę już wyjechać. Jadę na Mediolan (adres: poste restante) do Rzymu, a potem do Paryża za jakieś dwa tygodnie ${ }^{56}$. Pozdrowienie i najlepsze życzenia wszystkim Państwu przesyłam

Jan Lemański

56 We włoskiej miejscowości Pallanza nad jeziorem Maggiore Lemański spędził cały wrzesień. Stąd planował przez Mediolan jechać do Rzymu, do przebywającego tam Stanisława Masłowskiego, ale mimo obietnic złożonych Masłowskiemu do Rzymu nie dotarł. Bawił około tygodnia w Mediolanie, potem dwa tygodnie w San Remo i ok. 20 października wyjechał do Paryża (Korespondencja Stanistawa Mastowskiego, op. cit., k. 19-24). W Paryżu przebywał nie dwa tygodnie, ale aż do początku grudnia $1910 \mathrm{r}$. 
Karta pocztowa, formatu $13,8 \times 9 \mathrm{~cm}, z$ widokiem jeziora Maggiore $i$ wyspy Bella; podpis: Lago Maggiore. Isola Bella. Na odwrocie tekst czarnym atramentem i adres: Wielmożny Pan / Stefan Żeromski / rue Ernest Cresson 22 / Paris. Stemple: Locarno 30 SET. io.

22.

[Mediolan, 4 października ı9ıo] Szanownemu i Kochanemu Stefanowi Żeromskiemu w wyżyn katedry Mediolanu ${ }^{57}$ pozdrowienie najserdeczniejsze przesyła Jan Lemański

${ }_{4} \mathrm{X}$ igro

Karta pocztowa, formatu $14 \times 9 \mathrm{~cm}, z$ czarno-biatym zdjeciem katedry w Mediolanie; podpis: Milano - Dettaglio del Duomo. Na odwrocie tekst czarnym atramentem i adres: Wielmożny Pan / Stefan Żeromski / 22 rue Ernest Cresson 22 / Paris. Stemple: Milano 4.Io.Io.

\section{3.}

[Paryż, 28 listopada I9ıo]

g. $2 \frac{1}{2}$

Drogi Panie Stefanie!

Najmocniej przepraszam Państwa, a osobliwie Panią, że dziś być nie mogłem na winogronach poprzedzanych innymi rzeczami. Powód, dla którego nie byłem, wytłumaczę w czwartek. Tymczasem ściskam Waszą dłoń i Pani, i Adasia J. Leman

Karta poczty pneumatycznej koloru szaroniebieskiego, formatu I4,4 ×II,2 cm. Tekst czarnym atramentem na jednej stronie, na odwrocie adres: Monsieur / Stefan Żeromski / 22, rue Ernest-Cresson (XIV). Datowniki paryskie: 28.II.Io.

57 Katedra Narodzin św. Marii w Mediolanie - jeden z największych i najwyższych kościołów gotyckich na świecie, budowany w latach 1386-1572, przebudowany w 1858 r. Dach katedry, ozdobiony rzeźbami i gargulcami, udostępniony jest dla turystów. 


\section{IV I912, Altvater - Freiwaldau \\ Öst.-Schlesien}

Kochany i Szanowny Panie Stefanie!

W ciszy i samotności wspominam o tych, których zaliczam do swoich bliskich. Po niedawnej śmierci matki czuję się bezdomnym ${ }^{5}$, osobliwie tu, w tym kraju, który był naszym, a jest obcym, i gdzie ponad zamek stary piastowski wzniosła się strażnica Habsburgów59. Co tam słychać u Was? Napiszcie kilka wyrazów. Ja zabawię tu do końca tego miesiąca, a potem wybieram się dalej, może wreszcie do Londynu przez Paryż $\dot{z}^{60}$ Rad bym Was tam zastać. Najserdeczniej Was pozdrawiam

Jan Lemański

Karta pocztowa, formatu 13,7 × 8,8 cm, z widokiem wieży; podpis: Altvatergebirge. Habsburgwarte, $32 \mathrm{~m}$ hoch, auf dem Altvater, $1490 \mathrm{~m}$. Na odwrocie tekst czarnym atramentem i adres: Wielmożny Pan / Stefan Żeromski / rue 22 Ernest-Cresson 22 / Paris. Stemple: Freiwaldau (czytelna tylko data dzienna 2); Paris 4 AVRIL I2.

Szanowna Pani!

Że odpowiedzieć na moją kartę było pilniej nie p. Stefanowi tylko Pani, więc nie on, jeno Pani otrzyma ten widok rozkwitłej wiosny. P. Stefana jednak proszę, mimo to lenistwo, ucałować i powiedzieć mu, że tak samo jak nie ma kopacz złota

58 Maria z Nadratowskich Lemańska (1845-1912) - matka Lemańskiego, zmarła 27 lutego 1912 r., pogrzeb odbył się 1 marca. Poeta był bardzo związany z matką, przez wiele lat mieszkał z nią i siostrą w Warszawie przy ul. św. Barbary. Po śmierci matki przeprowadził się z siostrą na ul. Klonową.

59 Wówczas niemieckie miasto Freiwaldau - dziś czeski Jeseník, dawniej polski Frywałdów - położone jest na Czeskim Śląsku, a historycznie na Dolnym Śląsku. Zostało założone w XIII w. przez biskupów wrocławskich jako część należącego do nich księstwa nyskiego. Po wojnach śląskich w $1742 \mathrm{r}$. większość ziem księstwa znalazła się w granicach Prus. Jedynie jego południowa część (m.in. z obecnym Jeseníkiem) przypadła Habsburgom. Najbardziej znanym zabytkiem miasta jest gotycka twierdza wodna, w XVIII w. przebudowana na zamek.

60 Niestety, nie wiadomo, czy Lemańskiemu udało się te plany zrealizować. 
wstrętu do swej łopaty, tak również nie przystało mieć odrazy do pióra autorowi arcydzieł. Adasia proszę też ode mnie odściskać. Pewno już duży i krzepki z niego chłop. Dziękuję najserdeczniej za współczucie. Karta sprawiła mi wielką radość. Najśliczniej Pani się kłaniam

J. Lemański

Znalazłem w tutejszej czytelni Popioty, „Rozdzióbiq nas kruki...” i Sutkowskiego. Przyjeżdża tu dużo Polaków na czerwiec i lipiec ${ }^{6 \mathrm{~T}}$.

Autograf: BN rkps 7349, k. 9. Karta pocztowa, formatu I4 $\times 9 \mathrm{~cm}$, z górskim wiosennym pejzażem. Na odwrocie tekst czarnym atramentem $i$ adres: Mme / Oktavia Żeromska / 22 rue Ernest-Cresson 22 / Paris. Stemple pocztowe nieczytelne.

Druk fragmentu w: W. Hendzel, Ironista i marzyciel. O życiu i twórczości Jana Lemańskiego, op. cit., s. 33 .

Jan Lemański

[brak daty]

Najuprzejmiej prosi, o ile ta rzecz będzie zamieszczona, o przysłanie mu egzemplarza $^{62}$.

Bilet wizytowy koloru kremowego, formatu $I I \times 6,5 \mathrm{~cm}$. Tekst czarnym atramentem pod nadrukiem: Jan Lemański.

61 Freiwaldau był popularnym uzdrowiskiem, również wśród Polaków. Tamtejsze czytelnie mogły dysponować jednym z trzech wydań Popiotów. Powieści z końca XVIII i początku XIX wieku, które wyszły nakładem Gebethnera i Wolffa w 1904, 1906 i 1910 r.; jednym z trzech wydań zbioru opowiadań „Rozdzióbia nas kruki, wrony”, podpisanego pseudonimem Maurycy Zych: pierwodrukiem krakowskim z 1896 r. (właśc. 1895) lub edycjami lwowskimi z 1901 (właśc. 1900) i 1905 r.; jednym z dwóch wydań dramatu Sułkowski, opublikowanego dwukrotnie w 1910 r. przez krakowską Spółkę Nakładową „Książka”.

62 Nie udało się ustalić daty ani okoliczności wpisu na bilecie wizytowym. 